\title{
Development of organs and tissues in lambs raised on Spanish mountain grassland
}

\author{
Javier Álvarez-Rodríguez ${ }^{1}$, Albina Sanz ${ }^{1}$, Margalida Joy ${ }^{1}$, Salomé Carrascoํㅜ, \\ Guillermo Ripoll $^{1}$, and Alfredo Teixeira ${ }^{2}$ \\ ${ }^{1}$ Centro de Investigación y Tecnología Agroalimentaria, Gobierno de Aragón, Avenida Montañana 930, Zip code \\ 50059 Zaragoza, Spain; and ${ }^{2}$ Escola Superior Agrária de Bragança. Centro de Investigaçao de Montanha. \\ P.O. Box 172. Zip code 5301-855. Bragança, Portugal. \\ Received 2 June 2008, accepted 15 September 2008.
}

\begin{abstract}
Álvarez-Rodríguez, J., Sanz, A., Joy, M., Carrasco, S., Ripoll, G. and Teixeira, A. 2009. Development of organs and tissues in lambs raised on Spanish mountain grassland. Can. J. Anim. Sci. 89: 37-45. The present study was conducted to establish the pattern of body development in grass-raised Churra Tensina lambs. Forty-nine single male lambs were slaughtered at three body-weight intervals, according to the commercial categories of suckling $(11.1 \pm 1.0 \mathrm{~kg}), \operatorname{light}(22.1 \pm 0.8 \mathrm{~kg})$ and heavy lamb $(32.0 \pm 2.9 \mathrm{~kg})$. Non-carcass and carcass components were recorded and the half left carcasses were completely dissected. Lambs showed a low growth rate of main organs in relation to empty body weight $(\mathrm{BW})(P<0.01)$. Skin + fleece and liver accompanied the rest of mass growth $(P>0.05)$. The allometric coefficients of forestomachs and large intestine were higher than that of the small intestine $(P<0.05)$. Joints related to locomotion had early development $(P<0.01)$, whereas those belonging to the trunk grew at faster rates than did carcass weight $(P<0.01)$. The fatty tissues had increased growth coefficients $(P<0.01)$, whereas bone and lean coefficients decreased $(P<0.01)$ with increasing carcass weight. Intermuscular fat attained greater growth rates in lambs slaughtered at light $\mathrm{BW}$ than in heavy lambs $(P<0.01)$. However, the former group displayed lower relative growth of pelvic-renal, subcutaneous and abdominal fat than the latter $(P<0.01)$. This trait might reflect improved investment of dietary energy towards deposition of adipose tissue through the increased digestive tract capacity.
\end{abstract}

Key words: Sheep, carcass, non-carcass, tissues, fat depots, allometric growth

\begin{abstract}
Álvarez-Rodríguez, J., Sanz, A., Joy, M., Carrasco, S., Ripoll, G. et Teixeira, A. 2009. Développement des organes et des tissus chez les agneaux élevés dans les pacages montagneux d'Espagne. Can. J. Anim. Sci. 89: 37-45. L'étude devait préciser comment se développe le corps des agneaux Churra Tensina engraissés à l'herbe. Quarante-neuf agneaux mâles ont été abattus à trois poids corporels différents selon les catégories commerciales d'agnelet $(11,1 \pm 1,0 \mathrm{~kg})$, d'agneau léger $(22,1 \pm$ $0,8 \mathrm{~kg}$ ) et d'agneau lourd $(32,0 \pm 2,9 \mathrm{~kg})$. Les auteurs ont consigné les parties de la carcasse et les autres parties puis entièrement disséqué le côté gauche de la carcasse. Les principaux organes des agneaux croissent lentement comparativement au poids de la carcasse vide $(P<0,01)$. La peau et la laine ainsi que le foie suivent le reste de l'accroissement pondéral $(P>0,05)$. Les coefficients allométriques du secteur gastrique antérieur et du gros intestin sont plus élevés que ceux de l'intestin grêle $(P<0,05)$. Les articulations associées à la locomotion se développent hâtivement $(P<0,01)$ alors que celles du tronc croissent plus vite que le poids de la carcasse $(P<0,01)$. Les tissus adipeux se caractérisent par un coefficient de croissance plus élevé $(P<0,01)$, tandis que les coefficients des os et de la viande maigre diminuent $(P<0,01)$ à mesure que le poids de la carcasse augmente. Le taux de croissance de la graisse intermusculaire est plus élevé chez les agneaux légers que chez les agneaux lourds $(P<0,01)$. Cependant, les sujets du premier groupe révèlent une plus faible croissance relative de la matière grasse pelvique-rénale, sous-cutanée et abdominale que ceux du second groupe $(P<0,01)$. Cette caractéristique pourrait traduire une meilleure utilisation de l'énergie des aliments pour le dépôt de tissu adipeux grâce à une capacité supérieure du tube digestif.
\end{abstract}

Mots clés: Moutons, carcasse, non-carcasse, tissus, dépôts de graisse, croissance allométrique

The study of differential growth allows one to understand the transformation of body composition from birth to maturity. Besides saleable meat, an animal's body is composed of non-carcass components which, depending on the cultural context, are considered as waste material that is thrown away (as in North America) or as delicacies that command a relative high price (as in many Mediterranean countries). Noncarcass organs and tissues represent an important part of the body components, accounting for around $16 \%$ of the overall commercial value of the live animal (Delfa et al. 1999).

Lean and fat tissues are the two main edible components of an animal's carcass, the former requiring lesser amounts of energy to lay down than the latter (Warriss 2004). In addition, the growth rate of lambs can be

Abbreviations: BW, body-weight; CP, crude protein; KKCF, kidney knob and channel fat; NDF, neutral-detergent fibre 
reduced or increased by the feeding system, and this can also affect the allometric coefficients of some body tissues, especially adipose tissue (Thériez et al. 1976). In practical terms, the knowledge of the pattern of body development in each breed is useful to predict whether certain lamb products might be managed without compromising the technical efficiency of the farming system together with desired market demands.

The most common lamb production system in the Mediterranean area, especially in Spain, is an intensive management system based on early weaning (around 45-60 d) and subsequent concentrate feeding in order to obtain light carcasses (called "Ternasco" or "Recental", $18-26 \mathrm{~kg}$ BW). This commercial type can also be obtained by raising lambs with dams on grasslands (Álvarez-Rodríguez et al. 2007; Joy et al. 2008), in agreement with the current policies of the European Union, which promote extensification and multifunctionality of farming systems.

However, heavy and suckling lambs from certain breeds are also offered to market. Therefore, knowledge of the pattern of development of organs and tissues may help to select an optimum slaughter weight for these genotypes. In the coarse-wooled Churra Tensina sheep, the heavy lamb is an ancient product, very common in the past, when most flocks were managed in a valleymountain transhumance system. Lambs born in spring were reared with their dams on different pasture communities until autumn, being slaughtered at 25-35 kg BW at 5-8 mo of age (Olleta et al. 1992). Suckling lamb $(9-12 \mathrm{~kg})$ is the traditional end-product within the dairy industry but recently interest has increased in farms specialized in meat production with marked forage seasonality, since ewe-lamb feeding costs are thus reduced. Furthermore, a consumer preference for suckling lamb over light lamb type has already been shown (Bernabéu and Tendero 2005).

The aim of this study was to establish the pattern of development of non-carcass components and saleable meat in pasture-raised lambs of Churra Tensina breed slaughtered at three commercial categories that cover a wide range of body-weights.

\section{MATERIAL AND METHODS}

A total of 49 single male lambs weighing $3.7 \pm 0.5 \mathrm{~kg}$ at birth were slaughtered at three BW intervals, according to three commercial categories: 1 , suckling lamb (11.1 \pm $1.0 \mathrm{~kg}, 34 \pm 3$ days old, $n=15) ; 2$, light lamb (22.1 \pm $0.8 \mathrm{~kg}, 82 \pm 10 \mathrm{~d}$ old, $n=19$ ); and 3 , heavy lamb $(32.0 \pm 2.9 \mathrm{~kg}, 183 \pm 12$ days old, $n=15)$.

The animals belonged to experimental flock of the $\mathrm{La}$ Garcipollera Research Station, located in the Spanish Pyrenees (lat. $42^{\circ} 37^{\prime} \mathrm{N}$, long. $0^{\circ} 30^{\prime} \mathrm{W}$ ). Suckling and light lambs were raised on permanent grassland in valleys (920-945 m above sea level; pasture quality: $22.6 \% \mathrm{CP}$, $46.7 \%$ NDF) with their dams. Heavy lambs were castrated at $35 \mathrm{~d}$ of age and were managed similarly to light lambs throughout the spring (until $75 \mathrm{~d}$ of age). In summer, they reached high mountain ranges and grazed on alpine meadows (1500-2200 $\mathrm{m}$ above sea level; pasture quality: $7.4 \% \mathrm{CP}, 65.3 \% \mathrm{NDF}$ ) with their dams. At $161 \mathrm{~d}$ of age, heavy lambs came back to permanent pastures in valleys over $20 \mathrm{~d}$, being supplemented daily with $0.25 \mathrm{~kg}$ of concentrate per animal.

Lamb average daily gain from birth to slaughter was calculated by difference between BW on these days divided by the duration of the raising period.

\section{Slaughter Procedure}

All lambs were slaughtered under the same conditions and in accordance with the laws of ethics and welfare of animals (European Union Directive No. 86/609/CEE 1986) in the experimental slaughterhouse of the CITA Research Institute in Zaragoza. There was no fasting period. Digestive tracts were collected immediately after slaughter and forestomachs, small intestine and large intestine were separated and weighed individually with their contents and without omental and mesenteric fat. Each organ was emptied of contents, rinsed repeatedly with water until clean, drained of excess water and reweighed. The empty BW was calculated as the slaughter BW minus the contents of the digestive tract. According to the slaughter procedure in the Mediterranean area, offal components were divided into two groups: edible offals (heart, lung-trachea, thymus, liver, spleen, gall bladder, kidneys, diaphragm, pancreas, bladder, testes and penis), known as red offal, plus the empty digestive tract, known as white offal; and the carcass by-products (head, fleece and sum of four feet). Pericardic, omental, and mesenteric fat, together with offal components, were weighed separately.

\section{Carcass Joints and Dissection}

Carcasses were cooled at $4^{\circ} \mathrm{C}$ for $24 \mathrm{~h}$, halved carefully and weighed. Thereafter, the kidney knob and channel fat (KKCF) was removed and weighed. The left side was cut into six standardized commercial joints (shoulder, flank, leg, neck, anterior rib and loin-rib) plus the tail (Fig. 1). Prior to dissection, the tail was separated from the body and the weight of tail fat was recorded. Each joint was weighed and dissected into lean, bone, subcutaneous fat, intermuscular fat and waste (major blood vessels, ligaments, tendons and thick connective tissue sheets associated with some lean), in a dissection room with a controlled environment. Carcass cuts and dissection were carried out following a standardized protocol (Colomer-Rocher et al. 1988). Total body fat was the sum of pericardic, omental, mesenteric, KKCF, subcutaneous, intermuscular and tail fats. Total carcass fat was regarded as the sum of subcutaneous fat, intermuscular fat and KKCF.

\section{Statistical Analysis of Relative Growth}

Overall weights of each organ and tissue are presented as mean and standard deviation, to characterize their variation within this population. Using slaughter BW, 


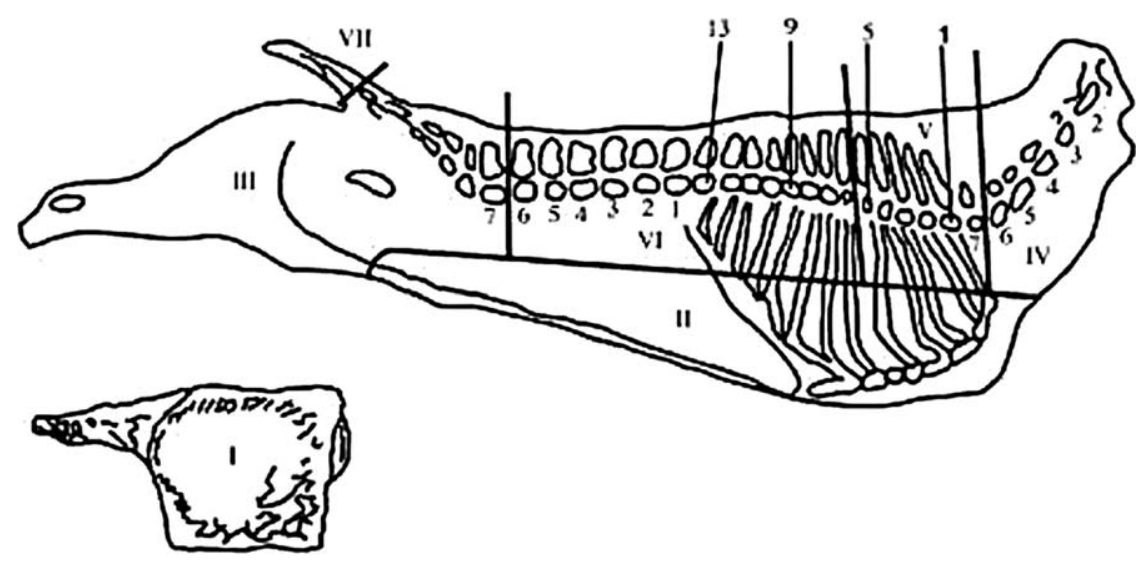

Fig. 1. Standard cuts in the Spanish lamb carcass (Colomer-Rocher et al. 1988). I, shoulder (removed); II, flank; III, leg; IV, neck; V, anterior rib; VI, Loin-ribs; VII, tail.

empty BW, half carcass weight, total carcass fat and total body fat weight as independent variables $(x)$, the relative growth coefficients $(b)$ for each carcass and body component $(y)$ were calculated from the allometric equation of Huxley (1932) $\left(y=\mathrm{a} x^{\mathrm{b}}\right)$.

The data were first log transformed (base 10) and weights of each component $(y)$ were then regressed on the independent variables $(x)$. This exponential relationship was converted to a logarithmic form to linearize the equation as follows:

$\log y=b \log x-\log a$

where $y$ is the carcass and body components; $x$ is slaughter BW, empty BW, half carcass weight, total carcass fat or total body fat; $a$ is the value of $y$ when $x=1$; and $b$ is the allometric growth coefficient.

The allometric growth coefficients for each dependent variable were tested for $b=1$ by means of their 95 and $99 \%$ confidence intervals (Steel and Torrie 1982). Additionally, they were compared using 95\% confidence intervals to determine the order of development within their associated independent variables.

\section{RESULTS}

The average daily gain from birth to slaughter was $227 \pm 9,230 \pm 6$ and $153 \pm 4 \mathrm{~g}$ in suckling, light and heavy lambs, respectively. Means, standard deviation and range of lamb characteristics at slaughter are shown in Table 1 .

\section{Non-carcass Components}

The main non-carcass organs showed an early-developing growth in relation to the empty $\mathrm{BW}(b<1, P<0.01$; Table 2). Kidneys, feet and heart were, in this order, the most precocious organs $(P<0.05)$. However, skin + fleece and liver had isometric coefficients of allometry ( $b=1, P>0.05)$, accompanying growth of the empty body.
The growth of the whole digestive tract accompanied the rest of body mass growth $(b=1 ; P>0.05$; Table 3$)$ whereas their separate components differed in their relative growth with respect to slaughter $\mathrm{BW}(\mathrm{b} \neq 1$, $P<0.05)$. The small intestine was the most early developing organ $(b<1, P<0.01)$, while forestomachs $(b>1, P<0.05)$ and large intestine $(b>1, P<0.01)$ displayed late growth in relation to body mass. Contents of all the digestive tract compartments grew at greater relative rates than did $\mathrm{BW}(b>1)$ (Table 4$)$.

\section{Carcass Joints}

The allometric coefficients of each carcass joint in relation to half carcass weight verified the shoulder, neck and leg developed earlier $(b<1, P<0.01$; Table 5) than the anterior rib, flank and loin-rib $(b>1, P<0.01)$. The tail displayed isometric growth in relation to half carcass weight $(b=1, P>0.05)$. Within early developing joints, the shoulder and neck showed faster relative growth than the leg $(P<0.05)$. However, the late joints (anterior rib, flank and loin-rib) developed at similar rates in relation to the rest of the carcass $(P>0.05)$. The most important carcass muscle, the 1. dorsi, showed an early development relative to half carcass weight ( $\left.b=0.91 \pm 0.03, P<0.01 ; R^{2}=0.95\right)$.

\section{Body and Carcass Tissues}

The relative growth of different body tissues in relation to empty BW is shown in Table 6 . Bone was the most precocious tissue $(b<1, P<0.01)$, followed by lean

Table 1. Means, standard deviation (SD) and range of lamb traits at slaughter

\begin{tabular}{lcc}
\hline Variable & Mean \pm SD & Range \\
\hline Age $(\mathrm{d})$ & $98.1 \pm 61.3$ & $28.0-196.0$ \\
BW $(\mathrm{kg})$ & $21.8 \pm 8.4$ & $8.8-37.2$ \\
Empty BW $(\mathrm{kg})$ & $19.1 \pm 7.1$ & $8.1-33.2$ \\
Half carcass weight $(\mathrm{kg})$ & $5.2 \pm 2.1$ & $2.1-9.2$ \\
\hline
\end{tabular}




\begin{tabular}{|c|c|c|c|c|}
\hline & Mean $\pm S D$ & $b \pm \mathrm{SE}$ & $R^{2}$ & $\begin{array}{c}\text { Order of } \\
\text { development }^{\mathbf{z}}\end{array}$ \\
\hline Kidneys & $78.6 \pm 16.6$ & $0.48 \pm 0.05^{* *}$ & 0.63 & 1 \\
\hline Feet (sum of four) & $573.9 \pm 150.8$ & $0.66 \pm 0.02 * *$ & 0.95 & 2 \\
\hline Heart & $107.9 \pm 31.6$ & $0.78 \pm 0.03^{* *}$ & 0.92 & $2-3$ \\
\hline Head & $964.6 \pm 273.8$ & $0.76 \pm 0.02 * *$ & 0.97 & 3 \\
\hline Lung and trachea & $413.2 \pm 139.6$ & $0.83 \pm 0.06^{* *}$ & 0.82 & 3 \\
\hline Spleen & $60.0 \pm 22.1$ & $0.84 \pm 0.06^{*}$ & 0.81 & $3-4$ \\
\hline Skin + fleece & $2178.6 \pm 874.5$ & $1.02 \pm 0.03$ & 0.96 & $4-5$ \\
\hline Liver & $379.5 \pm 143.0$ & $1.06 \pm 0.04$ & 0.93 & 5 \\
\hline
\end{tabular}

${ }^{\mathrm{z}}$ Different order of development denote differences $(P<0.05)$ among allometric growth coefficients of organs. $\mathrm{SD}=$ standard deviation, $\mathrm{SE}=$ standard error.

$* b \neq 1$ for $P<0.05, * * b \neq 1$ for $P<0.01$.

\begin{tabular}{lcccc}
\hline \multicolumn{1}{l}{ Table 3. Weights (g) and allometric coeficients $(\boldsymbol{b})$ of digestive tract organs in relation to slaughter BW } & \\
\hline & Mean $\pm \mathrm{SD}$ & $b \pm \mathrm{SE}$ & $R^{2}$ & Order of development $^{\mathbf{z}}$ \\
\hline Whole digestive tract & $1321.7 \pm 505.4$ & $1.03 \pm 0.06$ & 0.84 & - \\
Small intestine & $623.6 \pm 201.7$ & $0.65 \pm 0.08^{* *}$ & 0.59 & 1 \\
Large intestine & $214.7 \pm 103.1$ & $1.24 \pm 0.10^{*}$ & 0.76 & 2 \\
Forestomachs & $483.3 \pm 245.1$ & $1.49 \pm 0.06^{* *}$ & 0.92 & 2 \\
\hline
\end{tabular}

${ }^{\mathrm{z}}$ Different order of development denote differences $(P<0.05)$ among allometric growth coefficients of digestive tract organs.

$\mathrm{SD}=$ standard deviation, $\mathrm{SE}=$ standard error

${ }^{*} b \neq 1$ for $P<0.05, * * b \neq 1$ for $P<0.01$.

$(b<1, P<0.05)$. Tail fat development was isometric $(b=1, P>0.05)$, whereas the remaining fat depots were late developing with respect to empty $\mathrm{BW}(b>1$, $P<0.01$, for intermuscular, mesenteric and omental fat; $b>1, P<0.05$, for subcutaneous fat). According to the $95 \%$ confidence intervals of the allometric coefficients, the relative growth (or order of fat deposition) during the empty BW growth was: tail fat, intermuscular fat, KKCF, subcutaneous fat, mesenteric fat and finally, omental fat.

The allometric coefficients of the different carcass tissues with respect to half carcass weight are depicted in Table 7. Bone and lean were early developing in relation to half carcass weight $(b<1, P<0.01)$, whereas all the fat depots matured later within the carcass $(b>1$, $P<0.01)$. Bone was more precocious than lean $(P<0.05)$, but the relative growth of fat depots with respect to half carcass weight were similar $(P>0.05)$.

Table 4. Weights (g) and allometric coeficients $(b)$ of digestive tract contents in relation to slaughter $\mathrm{BW}$

\begin{tabular}{lccc}
\hline & Mean $\pm \mathrm{SD}$ & $b \pm \mathrm{SE}$ & $R^{2}$ \\
\hline Whole digestive tract & $2716.3 \pm 1655.7$ & $1.88 \pm 0.14^{* *}$ & 0.79 \\
Forestomachs & $1983.1 \pm 1267.3$ & $1.80 \pm 0.12^{* *}$ & 0.82 \\
Small intestine & $358.1 \pm 233.6$ & $1.82 \pm 0.18^{* *}$ & 0.68 \\
Large intestine & $403.7 \pm 262.3$ & $1.88 \pm 0.16^{* *}$ & 0.76 \\
\hline
\end{tabular}

$\mathrm{SD}=$ standard deviation, $\mathrm{SE}=$ standard error.

$* * b \neq 1$ for $P<0.01$.
Intermuscular fat, which developed late in relation to empty BW, developed early when the term of reference was total carcass fat $(b<1, P<0.01$; Table 8$)$. kidney knob and channel fat and subcutaneous fat were late developing in relation to total carcass fat $(b>1$, $P<0.01)$, and had similar growth rates $(P>0.05)$.

Tail fat and intermuscular fat showed early relative growth in relation to total body fat $(b<1, P<0.01$; Table 8). In turn, mesenteric fat, KKCF and subcutaneous fat accompanied the total body fat growth, with isometric coefficients of allometry $(b=1, P<0.05)$. Omental fat was the latest developing fat depot $(b>1$, $P<0.01)$.

Table 5. Weights (g) and allometric coeficients $(b)$ of carcass joints in relation to half carcass weight

\begin{tabular}{lcccc}
\hline & Mean \pm SD & \multicolumn{1}{c}{$b \pm \mathrm{SE}$} & $R^{2}$ & $\begin{array}{c}\text { Order of } \\
\text { development }\end{array}$ \\
\hline Shoulder & $1038.9 \pm 370.5$ & $0.90 \pm 0.01^{* *}$ & 0.99 & 1 \\
Neck & $381.8 \pm 130.1$ & $0.85 \pm 0.03^{* *}$ & 0.94 & 1 \\
Leg & $1708.0 \pm 632.5$ & $0.95 \pm 0.01^{* *}$ & 0.99 & 2 \\
Tail & $64.9 \pm 24.6$ & $0.90 \pm 0.08$ & 0.74 & $1-2-3$ \\
Anterior rib & $391.6 \pm 163.3$ & $1.08 \pm 0.03^{* *}$ & 0.97 & 3 \\
Flank & $572.4 \pm 241.7$ & $1.10 \pm 0.02^{* *}$ & 0.98 & 3 \\
Loin-rib & $1100.6 \pm 528.1$ & $1.14 \pm 0.03^{* *}$ & 0.96 & 3
\end{tabular}

${ }^{\mathrm{z}}$ Different order of development denote differences $(\mathrm{P}<0.05)$ among allometric growth coefficients of carcass joints. $\mathrm{SD}=$ standard deviation, $\mathrm{SE}=$ standard error .

$* * b \neq 1$ for $P<0.01$. 


\begin{tabular}{|c|c|c|c|c|}
\hline & Mean \pm SD & $b \pm \mathrm{SE}$ & $R^{2}$ & Order of development ${ }^{\mathbf{z}}$ \\
\hline Bone plus remainder & $1014.4 \pm 311.7$ & $0.81 \pm 0.02 * *$ & 0.97 & 1 \\
\hline Lean & $2855.1 \pm 1033.7$ & $0.96 \pm 0.02 *$ & 0.99 & 2 \\
\hline Tail fat & $28.8 \pm 15.2$ & $1.07 \pm 0.14$ & 0.55 & $1-2-3$ \\
\hline Intermuscular fat & $597.1 \pm 302.6$ & $1.24 \pm 0.06^{* *}$ & 0.90 & 3 \\
\hline Kidney knob and channel fat & $385.3 \pm 230.7$ & $1.43 \pm 0.15^{* *}$ & 0.66 & $3-4$ \\
\hline Subcutaneous fat & $419.4 \pm 309.0$ & $1.40 \pm 0.15^{*}$ & 0.64 & $3-4$ \\
\hline Mesenteric fat & $276.0 \pm 183.7$ & $1.73 \pm 0.07 * *$ & 0.93 & 4 \\
\hline Omental fat & $390.4 \pm 340.8$ & $2.15 \pm 0.11 * *$ & 0.89 & 5 \\
\hline
\end{tabular}

${ }^{\mathbf{z}}$ Different order of development denote differences $(\mathrm{P}<0.05)$ among allometric growth coefficients of body tissues.

$\mathrm{SD}=$ standard deviation, $\mathrm{SE}=$ standard error.

$* b \neq 1$ for $P<0.05, * * b \neq 1$ for $P<0.01$.

\section{DISCUSSION}

The data set showed substantial variation in order to represent a wide range of carcasses of Churra Tensina (Table 1) and allowed for an accurate estimation of most of the different allometric coefficients. The allometric relationships were used to describe the overall maturing pattern of non-carcass and carcass components over a wide range of lamb $\mathrm{BW}$, which might produce potentially viable carcasses. Notwithstanding, this methodology has been considered a constrained form to estimate relative maturing rates with a linear model, but omitting mature weights of body components, which are needed to fit non-linear growth models (Butterfield 1988).

Prud'Hon (1976) discussed the possibility of defining sheep "degree of maturity" as:

\section{$($ slaughter $\mathrm{BW} /$ adult $\mathrm{BW}) \times 100$.}

This parameter was not exactly known in the present study; however, errors might be small if we consider as "adult BW" the average BW of adult animals of the same breed and sex in medium body condition. Mature BW was estimated as the average of 21 adult males belonging to three representative flocks of this breed, including the flock of origin of these animals: $66.0 \pm$ $11.6 \mathrm{~kg}$ (unpublished observations). Thereby, each

Table 7. Allometric coeficients (b) of carcass tissues in relation to half carcass weight

\begin{tabular}{lccc}
\hline Carcass tissues $(\mathrm{g})$ & $b \pm \mathrm{SE}$ & $R^{2}$ & $\begin{array}{c}\text { Order of } \\
\text { development }^{\mathbf{z}}\end{array}$ \\
\hline Bone plus remainder & $0.79 \pm 0.02^{* *}$ & 0.96 & 1 \\
Lean & $0.94 \pm 0.01^{* *}$ & 0.99 & 2 \\
Intermuscular fat & $1.22 \pm 0.06^{* *}$ & 0.91 & 3 \\
Kidney knob and & $1.42 \pm 0.14^{* *}$ & 0.68 & 3 \\
$\quad$ channel fat & $1.42 \pm 0.14^{* *}$ & 0.69 & 3 \\
\hline
\end{tabular}

${ }^{\mathbf{z}}$ Different order of development denote differences $(\mathrm{P}<0.05)$ among allometric growth coefficients of carcass tissues.

$\mathrm{SE}=$ standard error

$* * b \neq 1$ for $P<0.01$. slaughtered lamb category accounted for around 15, 35 and $50 \%$ degree of maturity in suckling, light and heavy lambs, respectively.

\section{Non-carcass Components}

Tissues essential for life processes (i.e., respiration and metabolism) would be expected to be highly developed at birth, whereas tissues associated with locomotion and energy storage would be less developed (Jenkins and Leymaster 1993). In fact, most visceral and thoracic organs, together with the feet and head, were proportionately greater at birth, with further slow postnatal growth $(b<1$; Table 2$)$, similar to previously reports on Segureña (Peña et al. 1989) and Texel lambs (Rosa et al. 2002). In this sense, Atti et al. (2003) and Mahouachi and Atti (2005) reported that the weight of offal components rich in bone and/or with a low metabolic activity (head, feet) are early maturating parts.

However, the relative growth rate of skin + fleece relative to empty $\mathrm{BW}$ was slightly lower in the present

Table 8. Allometric coeficients (b) of different carcass fat tissues in relation to total carcass fat (1) or total body fat (2)

\begin{tabular}{llcc}
\hline Fatty tissues (g) & $b \pm \mathrm{SE}$ & $R^{2}$ & $\begin{array}{c}\text { Order of } \\
\text { development }\end{array}$ \\
\hline Carcass fat (1) & & & \\
Intermuscular fat & $0.86 \pm 0.03^{* *}$ & 0.93 & 1 \\
Kidney knob and channel fat & $1.15 \pm 0.05^{* *}$ & 0.94 & 2 \\
Subcutaneous fat & $1.15 \pm 0.04^{* *}$ & 0.95 & 2 \\
Body fat (2) & & & \\
Tail fat & $0.71 \pm 0.09^{* *}$ & 0.57 & 1 \\
Intermuscular fat & $0.83 \pm 0.03^{* *}$ & 0.96 & 1 \\
Mesenteric fat & $1.07 \pm 0.06$ & 0.85 & 2 \\
KKCF & $1.08 \pm 0.05$ & 0.90 & 2 \\
Subcutaneous fat & $1.08 \pm 0.05$ & 0.91 & 2 \\
Omental fat & $1.42 \pm 0.06^{* *}$ & 0.93 & 3 \\
\end{tabular}

${ }^{\mathrm{z}}$ Different order of development within carcass fat or body fat denote differences $(P<0.05)$ among allometric growth coefficients of fat depots.

$\mathrm{SE}=$ standard error.

$* * b \neq 1$ for $P<0.01$. 
lambs compared with those for Rambouillet, Dorset and Finn lambs (Notter et al. 1983). Similarly, the growth coefficients of skin + fleece, liver, lungs-trachea and spleen were indeed of earlier development here than in Manchega lambs (Ruiz de Huidobro and Cañeque 1994). As all these animals were slaughtered within a similar range of $\mathrm{BW}$, we hypothesized that differences might be related to variation in the stage of maturity at slaughter and in the energy-protein ratio of diets supplied to animals, which might have constrained the growth of these organs.

Accordingly, low-energy diets (such as those provided by forage-based feeding), might lower growth of skin + fleece, liver and kidneys in relation to empty BW compared with high-energy diets (such as those supplied by concentrate-based feeding). A restricted nutritional level increases the efficiency of feed utilization for gain (Fluharty and McClure 1997), possibly through the size decrease of visceral organs as a consequence of their reduced metabolic activity in such conditions (Burrin et al. 1990; Aziz et al. 1993).

The allometric growth coefficients of the digestive tract organs (Table 3) are in agreement with those of several sheep breeds referenced in the literature (Peña et al. 1989; Ruiz de Huidobro and Cañeque 1994; Rosa et al. 2002). Lyford (1993) stated that the small intestine increased rapidly until 8-9 wk of age, and then stopped to allow the growth of the forestomach at the same time that the lamb increased solid food intake. Moreover, this author reported that forestomachs displayed a clear dominant growth from 12 to $16 \mathrm{wk}$ of age. In this sense, Alvarez-Rodriguez et al. (2007) have shown that light lambs at pasture without any energetic supplement apart from dams' milk increased their grazing time from 2 to $5 \mathrm{~h}$ a day between 3 and $7 \mathrm{wk}$ of age.

Even though the growth rate of the small intestine was reduced with advancing age $(b<1$; Table 4$)$, the fill of this organ grew at a higher rate than did body mass $(b>1)$. As the rumen and small intestine are primary absorptive sites, this characteristic might have highlighted a homeostatic mechanism to cope with potentially limited glucose absorption as a consequence of the grass-based diet, following the steady decrease in milk yield of dams after 6 wk post-partum (Joy et al. 2008). In this sense, Cant et al. (1996) concluded that the maximum uptake capacity of the small intestine for glucose at any moment in time is a function of its length or weight, as well as some other parameters related to the flow rate and digesta kinetics.

\section{Carcass Joints}

The joints related to locomotion (leg, shoulder and neck) developed early $(b<1$; Table 5$)$. Ruiz de Huidobro and Cañeque (1994) also showed the same three early-developing joints in Manchega breed lambs. Likewise, the low relative growth of leg is in keeping with results found in Ile de France (Santos et al. 2000), Churra Galega Bragançana and Suffolk (Rodrigues et al. 2003), Gallega (Luaces et al. 2007), as well as in Churra da Terra Quente breed (Santos et al. 2007), among others. Nevertheless, the shoulder and neck were isometric joints $(b=1)$ in some previous reports (Santos et al. 2000; Rodrigues et al. 2003; Luaces et al. 2007; Santos et al. 2007). Even though wholesale cuts procedure differed among countries, the early growth of body components related to movement of lambs in the present work was probably a result of their increased outdoor exercise.

In the present study, flank was late developing $(b>1)$, similar to earlier studies that used silage and hay in the fattening diet (Luaces et al. 2007), but in contrast to those that used a concentrate-based diet (Ruiz de Huidobro and Cañeque 1994), in which flank growth accompanied the rest of carcass weight increase $(b=1)$. A possible explanation might be that flank composition is normally influenced by the feeding system, this joint being leaner in grass-fed than in concentrate-fed lambs (Murphy et al. 1994).

Loin-rib grew more rapidly than did carcass weight $(b>1)$, whereas the major lean contained in this joint (1. dorsi) grew less rapidly than did carcass weight $(b<1)$. This trend might indicate that loin-rib fatty tissue is rather late developing, being mainly noticeable at high carcass weights. In general, trunk joints (loin-rib and anterior rib) have been shown to grow more rapidly than carcass weight, regardless of the genotype or the management system (Ruiz de Huidobro and Cañeque 1994; Santos et al. 2000; Rodrigues et al. 2003; Luaces et al. 2007).

\section{Body and Carcass Tissues}

The weights of bone and lean increased less rapidly than did empty BW and carcass weight ( $b<1$; Table 6 and 7), indicating that both tissues decrease as a proportion of empty BW and carcass weight as maturity approaches. In contrast, the main fat depots developed late relative to empty BW and carcass weight $(b>1)$. This was expected because tissue maturation follows the order of bone, lean and fat (Rouse et al. 1970).

This general pattern has already been described in Australian Merino (Butterfield and Thompson 1983), Segureña (Domenech et al. 1989), Manchega (Ruiz de Huidobro and Cañeque 1994), Ile de France (Santos et al. 2000), Churra Galega Bragançana and Suffolk (Rodrigues et al. 2002) and Churra da Terra Quente breeds (Santos et al. 2007), among others. All the aforementioned studies agree in classifying lean as intermediate developing between bone and fat, but some of them found that its relative growth accompanied the rest of the carcass $(b=1)$ (Ruiz de Huidobro and Cañeque 1994; Rodrigues et al. 2002; Santos et al. 2007). Again, the differences amongst these studies are likely a consequence of environmental effects, probably related to diet quality and the degree of maturity attained at the slaughter BW. 
Although the lambs in the present study were mainly milk and pasture fed throughout the studied growing period, the energy provided through these feedstuffs was enough to allow fattening in the late phase prior to slaughter, without compromising growth of lean tissue. The energy supplement supplied to heavy lambs during the last month of fattening (from 28 to $32 \mathrm{~kg} \mathrm{BW}$ ) might have accounted for just $25 \%$ of the daily intake, as grass intake in growing lambs receiving a similar amount of supplement was 0.7 to $1.0 \mathrm{~kg} \mathrm{~d}^{-1}$ in a similar genotype (Churra da Terra Quente) and stage of maturity (40-65\%) (Lourenço et al. 2000).

The growth of tail fat accompanied the rest of the empty body growth ( $b=1$; Table 6 ), whereas carcass and digestive tract fat depots were late-maturing relative to the rest of the empty body $(b>1)$, accounting for low growth during early life. The latest fat depots to develop in relation to the empty BW were the mesenteric and omental fats, which support the lower killing-out proportions observed in the heavy lamb (Sanz et al. 2008). Tail fat was highly variable, which did not allow the accurate determination of growth coefficients using an allometric model of growth. Furthermore, the fat growth pattern in relation to empty BW differed from fat-tailed breeds, in which tail fat is late developing and noncarcass fat is an early-maturing depot (Negussie et al. 2003). Similarly, tail fat deposition was found to play a minor role in body reserve dynamics in medium-wooled breeds, such as Rasa Aragonesa (Teixeira et al. 1989).

The intermuscular fat was an early-maturing depot compared with the rest of the carcass or body fat depots $(b<1$; Table 8$)$. Kidney knob and channel fat and subcutaneous fat were late developing in relation to total carcass fat $(b>1)$, but isometric in relation to body fat $(b=1)$. The carcass fat growth pattern showed a high growth rate relative to carcass weight as maturity approached $(b>1)$. These outcomes are in line with those obtained in crossbred lambs of Suffolk $\times$ Churra da Terra Quente breed fed a concentrate-based diet (Teixeira and Azevedo 1989). Abdominal fat developed later in the present study than in the previous one, in which mesenteric fat grew less rapidly than did body fat $(b<1)$, and omental fat was isometric $(b=1)$ in relation to body fat. This difference might be due to the lower concentrations of fat precursors (i.e., propionic acid) resulting from digestion of fibre compared with starchbased diets (Moloney 1998).

Although slight differences arose in the growth rate of certain fat depots relative to body fat, the overall order of development of fatty tissues was in agreement with some earlier studies in Australian Merino (Butterfield and Thompson 1983) and Clun and Southdown breed lambs (Butler-Hogg 1984). However, the order of development of body fat differed from the one described in adult Rasa Aragonesa ewes slaughtered over a wide range of body condition scores: mesenteric, intermuscular, omental, KKCF and subcutaneous fat (Teixeira et al. 1989), probably because fat mobilization and deposition in mature animals causes alterations to the common growth trend.

It is noteworthy that in this study both $\mathrm{KKCF}$ and subcutaneous fat grew at very similar rates in relation to carcass fat and body fat as well as in relation to carcass weight, whereas in other reports $\mathrm{KKCF}$, but not subcutaneous fat, showed an early development in relation to these components (Ruiz de Huidobro and Cañeque 1994; Santos et al. 2000). This finding would support the use of KKCF as a reliable indicator of the degree of carcass fatness in pasture-raised animals from this breed, as suggested for other genotypes and production systems (Alcalde et al. 1999).

In summary, pasture-raised lambs from Churra Tensina breed show a low growth rate of vital organs in relation to the rest of the body components. Digestive tract compartments differ in their relative growth weight, but not in the growth of fill weight with respect to body-weight. Joints related to locomotion have an early development, whereas those belonging to the trunk grow at higher rates than carcass weight. The fatty tissues had increased growth coefficients whereas those for bone and lean were decreased with increasing carcass weight. Intermuscular fat attains greater growth rates in lambs slaughtered at light BW than in heavy lambs. However, the former group displays a lesser relative growth of the remaining fat depots $(\mathrm{KKCF}$, subcutaneous and abdominal fat) than the latter. In grazing lambs, this trait might reflect the improved investment of dietary energy towards deposition of adipose tissue through the increased digestive tract capacity.

\section{ACKNOWLEDGEMENTS}

The authors thank R. Delfa (in memoriam), B. Panea and the staff of La Garcipollera and CITA de Aragón for their technical assistance. This study was supported by INIA projects (INIA RZ-2004-0028, Ministry of Education and Science of Spain and European Union Regional Development Funds). J. Álvarez-Rodríguez receives a grant from the INIA-DGA.

Alcalde, M. J., Sañudo, C., Osorio, J. C., Olleta, J. L. and Sierra, I. 1999. Evaluación de la calidad de la canal y de la carne en canales ovinas ligeras del tipo comercial "Ternasco". ITEA 95A: 49-64.

Álvarez-Rodríguez, J., Sanz, A., Delfa, R., Revilla, R. and Joy, M. 2007. Performance and grazing behaviour of Churra Tensina sheep stocked under different management systems during lactation on Spanish mountain pastures. Livest. Sci. 107: 152161 .

Atti, N., Ben Salem, H. and Priolo, A. 2003. Effects of polyethylene glycol in concentrate or feed blocks on carcass composition and offal weight of Barbarine lambs fed Acacia cyanophylla Lindl. foliage. Anim. Res. 52: 363-375.

Aziz, N. N., Murray, D. M. and Ball, R. O. 1993. The effect of live weight gain and live weight loss on body composition of Merino wethers: noncarcass organs. J. Anim. Sci. 71: 400-407. 
Bernabéu, R. and Tendero, A. 2005. Preference structure for lamb meat consumers. A Spanish case study. Meat Sci. 71: 464-470.

Burrin, D. G., Ferrell, C. L., Britton, R. A. and Bauer, M. 1990. Level of nutrition and visceral organ size and metabolic activity in sheep. Br. J. Nutr. 64: 439-448.

Butler-Hogg, B. W. 1984. The growth of Clun and Southdown sheep: body composition and the partitioning of total fat. Anim. Prod. 39: 405-411.

Butterfield, R. M. 1988. New concepts of sheep growth. Griffin Press, Australia.

Butterfield, R. M. and Thompson, J. M. 1983. Changes in body composition relative to weight and maturity in large and small strains of Australian Merino rams. 4. Fat depots and bones. Anim. Prod. 37: 423-431.

Cant, J. P., McBride B. W. and Croom, W. J., Jr. 1996. The regulation of intestinal metabolism and its impact on whole animal energetics. J. Anim. Sci. 74: 2541-2553.

Colomer-Rocher, F., Delfa, R. and Sierra, I. 1988. Método normalizado para el estudio de los caracteres cuantitativos y cualitativos de las canales ovinas producidas en el área mediterránea, según los sistemas de producción. in Programa AGRIMED-CIHEAM: "Les carcasses d'agneux et de chevreaux méditerranéens", 9-10 December, Zaragoza. Published in French: EEC, Rapport EUR 11479 FR. Published in Spanish: Cuadernos INIA 17, 19-41.

Delfa, R., Gosálvez, L. F., Tor, M. and González, C. 1999. El quinto cuarto en ternascos de raza Roya Bilbilitana y Ojinegra de Teruel. Rev. Portug. Zootec. VI: 101-112.

Domenech, V., Peña, F., Aparicio, F., Tovar, J. and Méndez, D. 1989. Crecimiento y desarrollo de los tejidos en canales de corderos de raza Segureña. Archiv. Zootech. 38(141): 189-203. European Union Directive No. 86/609/CEE, 1986. Council Directive of 24 November 1986 on the approximation of laws, regulations and administrative provisions of the Member States regarding the protection of animals used for experimental and other scientific purposes. Official Journal of the European Communities, Serie L358: 1-32.

Fluharty, F. L. and McClure, K. E. 1997. Effects of dietary energy intake and protein concentration on performance and visceral organ mass in lambs. J. Anim. Sci. 75: 604-610.

Huxley, J. S. 1932. Problems of relative growth. Methuen, London, UK.

Jenkins, T. G. and Leymaster, K. A. 1993. Estimates of maturing rates and masses at maturity for body components of sheep. J. Anim. Sci. 71: 2952-2957.

Joy, M., Álvarez-Rodríguez, J., Revilla, R., Delfa, R. and Ripoll, G. 2008. Ewe metabolic performance and lamb carcass traits in pasture and concentrate-based production systems in Churra Tensina breed. Small Rum. Res. 75: 24-35.

Lourenço, A. L. G., Dias-da-Silva, A. A., Fonseca, A. J. M. and Azevedo, J. T. 2000. Effects of live weight, maturity and genotype of sheep fed a hay-based diet, on intake, digestion and live weight gain. Livest. Prod. Sci. 63: 291-296.

Luaces, M. L., Calvo, C., Fernández, A., Viana, J. L., Fernández, B. and Sánchez, L. 2007. Estudio de las piezas comerciales y su desarrollo en canales de corderos de la raza ovina Gallega. Arch. Zootec. 56 (214): 157-168.

Lyford, S. J. 1993. El rumiante: fisiología digestiva y nutrición. Pages 47-68 in Crecimiento y desarrollo del aparato digestivo de los rumiantes. Acribia, Zaragoza, Spain.
Mahouachi, M. and Atti, N. 2005. Effects of restricted feeding and re-feeding of Barbarine lambs: intake, growth and noncarcass components. Anim. Sci. 81: 305-312.

Moloney, A. P. 1998. Growth and carcass composition in sheep offered isoenergetic rations which resulted in different concentrations of ruminal metabolites. Livest. Prod. Sci. 56: $157-164$.

Murphy, T. A., Loerch, S. C., McClure, K. E. and Solomon, M. B. 1994. Effects of grain or pasture finishing systems on carcass composition and tissue accretion rates of lambs. J. Anim. Sci. 72: 3138-3144.

Negussie, E., Rottmann, O. J., Pirchner, F. and Rege, J. E. O. 2003. Patterns of growth and partitioning of fat depots in tropical fat-tailed Menz and Horro sheep breeds. Meat Sci. 64: 491-498.

Notter, D. R., Ferrell, C. L. and Field, R. A. 1983. Effects of breed and intake level on allometric growth patterns in ram lambs. J. Anim. Sci. 56: 380-395.

Olleta, J. L., Sañudo, C. and Sierra, I. 1992. Producción de carne en la agrupación ovina Churra Tensina: cordero pastenco y de cebo. ITEA 88A: 119-128.

Peña, F., Domenech, V., Aparicio, F. and Méndez, D. 1989. Características de la canal en corderos de raza Segureña. I. Componentes corporales no incluidos en la canal. Archiv. Zootec. 38 (141): 107-125.

Prud'Hon, M. 1976. La croissance globale de l'agneau: ses caracteristiques et ses lois. Pages 6-26 in 2émes Journees de la Recherche Ovine et Caprine, ITOVIC, Paris, France.

Rodrigues, S., Cadavez, V., Matos, S., Pereira, E., Delfa, R. and Teixeira, A. 2002. Alometria dos tecidos da carcaça em cordeiros das raças Churra Galega Bragançana e Suffolk. Pages 633-636 in XII Congresso de Zootecnia, Associaçăo Portuguesa dos Engenheiros Zootécnicos.

Rodrigues, S., Cadavez, V., Pereira, E., Delfa, R. and Teixeira, A. 2003. Alometria das peças de talho em cordeiros das raças Churra Galega Bragançana e Suffolk. Page 90 in Produzir qualidade em segurança. Livro de resumos, XIII Congresso de Zootecnia, Associaçăo Portuguesa dos Engenheiros Zootécnicos.

Rosa, G. T., Pires, C. C., Silva, J. H. S. and Motta, O. S. 2002. Proporções e Coeficientes de Crescimento dos não-Componentes da Carcaça de Cordeiros e Cordeiras em Diferentes Métodos de Alimentação. R. Bras. Zootec. 31: 2290-2298.

Rouse, G. H., Topel, D. G., Vetter, R. L., Rust, R. E. and Wickersham, T. W. 1970. Carcass composition of lambs at different stages of development. J. Anim. Sci. 31: 846-855.

Ruiz de Huidobro, F. and Cañeque, V. 1994. Producción de carne de corderos de raza Manchega. 5. Crecimiento relativo del quinto cuarto y de los tejidos y piezas de la canal. Inv. Agr. Prod. San. Anim. 9: 95-108.

Santos, A. V. C., Silva, S. R., Mena, E. G. and Azevedo, J. M. T. 2007. Body-weight and sex effects on carcass and meat quality of "Borrego terrincho-PDO" suckling lambs. Meat Sci. 77: 654-661.

Santos, V., Azevedo, J. and Silva, S. 2000. Crescimento relativo dos vários componentes corporais de borregos da raça Ile-deFrance. Rev. Portug. Zootec. VII: 29-41.

Sanz, A., Álvarez-Rodríguez, J., Cascarosa, L., Ripoll, G., Carrasco, S., Revilla, R. and Joy, M. 2008. Características de la canal de los tipos comerciales de cordero lechal, ternasco y pastenco en la raza Churra Tensina. ITEA 104: 42-57. 
Steel, R. G. D. and Torrie, J. H. 1982. Principles and procedures of statistics. A biometrical approach, 3rd ed. McGraw Hill, Tokyo, Japan.

Teixeira, A. and Azevedo, J. 1989. Crescimento relativo dos diversos componentes do peso vivo e da carcaça determinados em borregos machos cruzados da raça Suffolk com a Churra da Terra Quente. Pages 97-104 in $1^{\circ}$ Congresso de Zootecnia, Comunicaçŏes, Associaçăo Portuguesa dos Engenheiros Zootécnicos.
Teixeira, A., Delfa, R. and Colomer-Rocher, F. 1989. Relationships between fat depots and body condition score or tail fatness in the Rasa Aragonesa breed. Anim. Prod. 49: 275-280. Thériez, M., Van Quackebeke, E. and Cazes, J. P. 1976. Influence de l'alimentation sur la croissance, l'etat d'engraissement et la qualité des carcasses. $2^{\text {iéme }}$ Journées de la Recherche Ovine et Caprine. INRA-ITOVIC.

Warriss, P. D. 2004. Meat science. An introductory text. CABI Publishing, CAB International, Wallingford, UK. 